\title{
In Vitro Microbial Degradation of Abnormal Prions in Central Nervous System from Scrapie Affected Sheep
}

\author{
Hongsheng Huang*, J. Lloyd Spencer and Jiewen Guan
}

\author{
Ottawa Laboratory Fallowfield (OLF), Canadian Food Inspection Agency, 3851 Fallowfield Road, Ottawa, Ontario, \\ K2H 8 P9, Canada
}

\begin{abstract}
Abnormal prion protein $\left(\mathrm{PrP}^{\mathrm{Sc}}\right)$ is highly resistant to inactivation by conventional chemical and physical means. This study was to determine if microbes from the environment could be used to degrade $\mathrm{PrP}^{\mathrm{Sc}}$ in central nervous system (CNS) tissues from scrapie positive sheep as measured by Western blot. In the first experiment, the number of microbes in CNS tissue suspended in saline was reduced by autoclaving the suspension at $121^{\circ} \mathrm{C}$ for 5 minutes. Aliquots of this preparation were then inoculated with additional ovine fecal microbes and controls were not inoculated. The results showed that the addition of microbes increased the degradation of $\operatorname{PrP}^{\mathrm{Sc}}$ in specimens during incubation at room temperature (RT) or at $60^{\circ} \mathrm{C}$, but the reduction was greatest at $60^{\circ} \mathrm{C}$. In the second experiment, a separate tissue suspension in saline was prepared from CNS tissue from each of 4 scrapie positive sheep and from each of 4 negative sheep. All specimens contained bacteria and after 90 days of incubation at $60^{\circ} \mathrm{C}, \mathrm{PrP}^{\mathrm{Sc}}$ in $\mathrm{CNS}$ specimens was degraded beyond the detection limit in tissues from 2 scrapie positive sheep and was partially degraded in the other two specimens. The tissues from scrapie negative sheep were consistently negative for $\mathrm{PrP}^{\mathrm{Sc}}$. Analysis of microbial 16S ribosomal DNA indicated that during the 90 day incubation period the microbe population shifted from a predominance of mesophiles to thermophiles, based on guanine-cytosine (GC) content of ribosomal RNA genes. The results in this study suggest that microbes commonly found in sheep carcasses or manure could play a role in the degradation of $\operatorname{PrP}^{\mathrm{Sc}}$ in $\mathrm{CNS}_{\mathrm{S}}$ tissues during incubation at $60^{\circ} \mathrm{C}$.
\end{abstract}

Keywords: Abnormal prion protein, transmissible spongiform encephalopathies (TSEs), scrapie, microbial degradation in vitro, thermophilic and mesophilic microbes, ovine feces.

\section{INTRODUCTION}

Transmissible spongiform encephalopathies (TSEs) are a group of fatal, degenerative neurological diseases that include scrapie in sheep and goats. The accumulation of abnormal prion protein $\left(\mathrm{PrP}^{\mathrm{Sc}}\right)$ of host cellular prion protein is associated with the pathogenesis of the disease and may be the causative agent or a major component of causative agent [1]. The $\operatorname{PrP}^{\mathrm{Sc}}$ is highly resistant to inactivation by conventional means which destroys microorganisms, nucleic acids and proteins [2] and this poses problems for disposal of carcasses. Procedures that appear to be able to reduce the infectivity of TSE agents to non-detectable levels include: exposure to dry heat at $1,000^{\circ} \mathrm{C}[3]$, incineration at $1000^{\circ} \mathrm{C}$ [4], immersion in strong solutions of sodium hypochlorite or sodium hydroxide [2]. Neither rendering nor deep burial of carcasses have been shown to completely destroy the infectivity [4-6]. Composting is a natural biological decomposition process and has recently been shown to be an effective means for disposal of animal carcasses [7]. Our recent study has given evidence that the composting process could degrade $\mathrm{PrP}^{\mathrm{Sc}}$ to levels that are not detectable by a highly sensitive Western blot (WB) [8], which indicated that microbial activities may play a role in the degradation of

*Address correspondence to this author at the Ottawa Laboratory Fallowfield (OLF), Canadian Food Inspection Agency (CFIA), 3851 Fallowfield Road, Ottawa, Ontario, K2H 8P9, Canada; Tel: +613-228-6698; Fax:+613-228-6669; E-mail: huangho@inspection.gc.ca
$\mathrm{PrP}^{\mathrm{Sc}}$. Other studies give evidence that $\mathrm{PrP}^{\mathrm{Sc}}$ is at least partially degraded by thermostable enzymes or protease from Bacillus sp. [9-11], Streptomyces sp. [12, 13] and Nocardiopsis sp. [14]. Likewise, undefined microbes in cheese [15] or in the rumen and colon of cattle [16, 17] may cause degradation. Temperature of incubation influenced the degradation process [9]. Furthermore, the infectivity of $\mathrm{PrP}^{\mathrm{Sc}}$ was reduced by thermostable subtilisin-enzyme [10]. The objective of this study was to further investigate the capacity of microbes from the environment relevant to sheep to degrade $\mathrm{PrP}^{\mathrm{Sc}}$ in $\mathrm{CNS}$ tissues from scrapie positive sheep under in vitro test tube conditions.

\section{MATERIALS AND METHODOLOGY}

\section{Tissues}

Frozen samples of tissue for testing were from the cerebrum or cerebellum and brain stem from natural classic scrapie positive or scrapie negative sheep submitted for diagnostic purposes in Canada. These samples were collected under non-sterile conditions and were frozen at $-20^{\circ} \mathrm{C}$ prior to use. The scrapie status was determined by immunohistochemical and histopathological procedures and the samples used were tested by WB [18] prior to experiments.

\section{In Vitro Simulation Study}

Exp. 1 investigated the influence of microbes and temperature of incubation on degradation of the $\mathrm{PrP}^{\mathrm{Sc}}$ in $\mathrm{CNS}$ 
tissue from scrapie infected sheep. Feces from healthy sheep in a flock that does not have a history of scrapie were used as a source of microbes which is an important source of microbes present in the environment relevant to sheep. Particularly the effects of incubation temperatures at room temperature (RT, $22 \pm 2^{\circ} \mathrm{C}$ ) and $60^{\circ} \mathrm{C}$ were compared based on the results of the previous composting study [8] and other studies $[10,12]$ that showed the positive correlation between the presence of thermophilic microbes or enzymes and $\mathrm{PrP}^{\mathrm{Sc}}$ degradation. In addition, a preliminary trial was carried out in this study to determine an appropriate temperature for optimal degradation of $\mathrm{PrP}^{\mathrm{Sc}}$. In this preliminary trial, the ovine fecal microbes were obtained from a healthy sheep in a flock without scrapie history by suspending the feces in saline at 1:10 and 1:100 dilutions. Each $100 \mu \mathrm{l}$ aliquot of $30 \%$ CNS tissue homogenates in sterile saline from a scrapie infected sheep was inoculated with $200 \mu \mathrm{l}$ of $1: 10$ or $1: 100$ diluted innocula and was incubated for 10 days at $\mathrm{RT}, 37^{\circ} \mathrm{C}, 50^{\circ} \mathrm{C}$ or $60^{\circ} \mathrm{C}$, respectively (triplicate for each treatment). After incubation for 10 days at the temperatures of $\mathrm{RT}, 37^{\circ} \mathrm{C}, 50^{\circ} \mathrm{C}$ and $60^{\circ} \mathrm{C}$ and with each increase of at least $10^{\circ} \mathrm{C}$ in temperature, there was a significant $(p<0.05)$ decrease in the intensity of the WB bands detected by WB (methods described below) for the samples inoculated with microorganisms. The detailed results were presented in the result section. Therefore, in the following experiments, only RT and $60^{\circ} \mathrm{C}$ were compared. A $60 \%$ tissue suspension was prepared by pooling equal amounts of CNS tissues from 5 sheep naturally infected with scrapie (13.9 $\mathrm{g}$ in total) that was then homogenized in $23.3 \mathrm{ml}$ of sterile saline ( $60 \%$ homogenate) containing Zirconia microbeads (BioSpec Products, Inc. Bartlesville, Oklahoma, USA) using a FastPrep ${ }^{\circledR}$ Cell Disrupter (Qbiogene SA, Carlsbad, California, USA) [8]. It was difficult to decontaminate brain tissue surface due to the small amount specimen available and the fragility of brain tissues. It was also not appropriate to use antibiotics which would inhibit the growth of inoculated microbes in this experiment. Therefore the tissue suspension was then autoclaved for 5 minutes at $121^{\circ} \mathrm{C}$. This treatment reduced the numbers of microbes but also reduced $\operatorname{PrP}^{\mathrm{Sc}}$ detected by $\mathrm{WB}$ by $13.2 \%$. Aliquots of the $60 \%$ homogenate prepared from the scrapie positive sheep were serially diluted with a similarly prepared $60 \%$ brain homogenate from a healthy scrapie negative sheep to obtain $6 \%$ and $0.6 \%$ scrapie positive homogenates. Six $\mathrm{ml}$ aliquots of suspension containing $60 \%, 6 \%$ and $0.6 \%$ scrapie positive tissue were then dispensed into $15 \mathrm{ml}$ size centrifuge tubes in preparation for inoculation with microbes from the feces of scrapie negative sheep.

The microbe inocula consisted of a $10 \%(\mathrm{w} / \mathrm{v})$ suspension of feces in saline that had been incubated in $15 \mathrm{ml}$ tubes with loose caps at RT or at $60^{\circ} \mathrm{C}$ and that had been subcultured 8 times about every two weeks in plate count (PC) broth (Oxoid, Ottawa, Ontario) at 1:10 ratio. The above culture conditions would allow obtaining either mesophilic or thermophilic microbes as relevant inocula. Tissue suspensions to be incubated at RT or at $60^{\circ} \mathrm{C}$ were inoculated at a 1:10 ratio with fecal microbes (approximately $10^{8} \mathrm{CFU} / \mathrm{ml}$ as determined using PC agar plates) that had been pre-incubated at the same temperature. Control tissue suspensions were inoculated with sterile media in lieu of the microbe suspension and these were also incubated at RT or $60^{\circ} \mathrm{C}$. The tube caps were kept loose to allow growth of aerobic microbes and all specimens were held in a Class II type B2 biological cabinet. A block heater was used for incubation at $60^{\circ} \mathrm{C}$. The specimens for testing were collected on days 1, 10 and 30 of incubation. The volume of the samples was kept constant before sample collection by adding sterile distilled water to correct for loss of volume $(10-20 \%$ of the original volume) by evaporation.

Exp. 2 studied the degradation of $\mathrm{PrP}^{\mathrm{Sc}}$ in $\mathrm{CNS}$ tissue suspensions that were contaminated with microbes at the time of collection but that had not been autoclaved and had not been inoculated with extra microbes. The CNS tissues were from 4 scrapie affected and 4 scrapie negative adult sheep. Three grams of tissue from each animal was kept separate and was minced in saline by chopping with sterile blades and was then gently vortexed to make a $60 \%$ homogenate. Eight $\mathrm{ml}$ of each tissue suspension was dispensed in a $15 \mathrm{ml}$ tube and all specimens were incubated at $60^{\circ} \mathrm{C}$. Two $\mathrm{ml}$ of well mixed sample suspension was collected on days $0,30,60$ and 90 of incubation and these were stored at $-20^{\circ} \mathrm{C}$ prior to testing. All work and incubation was performed inside a Class II type B2 biological cabinet.

\section{Western Blot Analysis}

The WB was performed following an enrichment procedure using sodium phosphotungstic acid (PTA) precipitation and reagents as previously described [18]. Briefly, the samples were adjusted to $20 \%$ (final concentration) in WB lysis buffer, homogenized and incubated for 30 minutes at RT. Next, $0.6 \mathrm{ml}$ of the homogenate was treated with an equal volume of $4 \%$ sarkosyl solution, followed by DNAse I and protease K (PK). The PK activity was stopped by Pefablock SC. The supernatant was then incubated with PTA at a final concentration of $0.3 \%$ followed by centrifugation at $16249 \times \mathrm{g}$ for 30 minutes. The pellet was resuspended in $12 \mu \mathrm{l}$ of water for testing or was stored at $-20^{\circ} \mathrm{C}$ if not tested immediately. The above samples were mixed with NuPAGE sample buffer and reducing agent (Invitrogen) and were electrophoresed [18] using NuPAGE pre-cast $12 \%$ gel and MOPS running buffer (Invitrogen). Proteins on gels were then electroblotted using semi-dry transfer apparatus (Bio-Rad Laboratories, Inc., Mississauga, Ontario, Canada) [18] onto a polyvinylidene fluoride (PVDF) membrane (Bio-Rad). PrP ${ }^{\mathrm{Sc}}$ was detected with monoclonal antibody F99/97.6.1 at 3.5 $\mu \mathrm{g} / \mathrm{ml}$ (VMRD, Inc. Pullman, WA, USA). This was followed by incubation with goat anti-mouse polyclonal serum conjugated with horse radish peroxidase. The membrane was incubated with chemiluminescent substrate, ECL Plus (Amersham Biosciences) for 5 minutes, and chemiluminescent signals were visualized by exposing the membrane to X-ray film or were captured using the ChemiDoc ${ }^{\mathrm{TM}}$ System (Bio-Rad). The density of the $\operatorname{PrP}^{\mathrm{Sc}}$ bands, defined as intensity of pixels $/ \mathrm{mm}^{2}$, was measured using the Quantity One program (Version 4.4, Discovery Series, BioRad). The reduction rate of $\operatorname{PrP}^{\mathrm{Sc}}$ was calculated using the following formula: reduction $\%=[1-($ density after incubation $/$ density on day 0$)$ ] x 100\%.

\section{Microbial Isolation and Analysis of Microbial 16S Ribosomal RNA Genes}

The CNS samples before and after in vitro incubation were plated on PC agar plates (Oxoid, Ottawa, Ontario) with 100,10 and $1 \mu 1$ of the original suspensions diluted in $1 \mathrm{ml}$ of PC broth with subsequent even spreading on plates and overnight incubation at $37^{\circ} \mathrm{C}$. The bacterial colonies were 
counted and the average numbers of CFU per $\mathrm{ml}$ from different dilutions were calculated.

For analysis of microbial 16S ribosomal DNA (16S rDNA) or16S ribosomal RNA (16S rRNA) genes in exp.1 and 2, the concentrations of samples were adjusted to $20 \%$ in saline. Briefly, DNA was extracted from the above lysed samples using the FastDNA kit for soil (Q-Biogene, Carlsbad, CA, USA), according to the manufacturer's instructions. The primary and nested polymerase chain reaction (PCR) used to amplify $16 \mathrm{~S}$ rRNA) genes or $16 \mathrm{~S}$ rDNA from total community DNA were performed as described previously $[19,20]$. Denaturing gradient gel electrophoresis (DGGE) was performed with a DCode universal mutation detection system and the DCode control reagent kit (Bio-Rad). The nested PCR products were analyzed using $6 \%(\mathrm{wt} / \mathrm{vol})$ acrylamide gels with a denaturing gradient from 20 to $80 \%$. The denaturing gradient gel was formed according to instructions supplied by the manufacturer (Bio-Rad Laboratories, Mississauga, ON, Canada). The electrophoresis was performed in 1 x TAE (40 $\mathrm{mM}$ Tris, $20 \mathrm{mM}$ acetic acid, $1 \mathrm{mM}$ EDTA, $\mathrm{pH} 8.3$ ) at a fixed voltage of $150 \mathrm{~V}$ and a fixed temperature of $60{ }^{\circ} \mathrm{C}$ for 5h. After electrophoresis, the gels were stained with 50 $\mu \mathrm{g} / \mathrm{ml}$ of ethidium bromide, and photographed with UV transillumination using a Chemi Doc ${ }^{\mathrm{TM}}$ system (Bio-Rad). The thermophilic microbe controls were that had been incubated at $60^{\circ} \mathrm{C}$ for over two months (first lane of Fig. 3A). Mesophilc microbe control was a Pseudomonas chlororaphis strain (lane 9 of Fig. 1B, 3A). The 16S rRNA genes or rDNA of thermophilic microbes have higher guanine-cytosine $(\mathrm{G}+\mathrm{C})$ content [21-23]; and bands appear at a higher density portion of the denaturing gradient or in the lower position of the gel than do the mesophilic microbes.

\section{Statistical Analysis}

For exp. 1, the reduction rates of $\mathrm{PrP}^{\mathrm{Sc}}$ band density in suspensions containing 60,6 and $0.6 \%$ scrapie brain tissues were combined and were compared between different treatments (with or without microbial inoculation at two different temperatures) on day 30 using paired Student's $t$-test (Microsoft Excel). The $\operatorname{PrP}^{\mathrm{Sc}}$ band densities for exp. 2 were analyzed using the analysis of variance (ANOVA, Microsoft Excel). $P$ values $\leq 0.05$ were considered significant.

\section{RESULTS}

\section{Degradation of PrP ${ }^{\mathrm{Sc}}$}

To choose the effective incubation temperature(s), a preliminary trial for the first experiment showed that after incubation for 10 days with each increase of at least $10^{\circ} \mathrm{C}$ in temperatures of $\mathrm{RT}, 37^{\circ} \mathrm{C}, 50^{\circ} \mathrm{C}$ and $60^{\circ} \mathrm{C}$, there was a significant $(p<0.05)$ decrease in the intensity of the WB bands detected by WB for the samples inoculated with microorganisms. The following are the densities of $\operatorname{PrP}^{\mathrm{Sc}}$ bands detected by WB for the samples after 10 day incubation with inoculation of microbial suspension: $3.6 \times 10^{5} \pm 1.1 \times 0^{5}$ (day 0 control), $4.8 \times 0^{5} \pm 8.9 \times 10^{3}$ (at RT), $1.7 \times 10^{5} \pm 5.3 \times 10^{4}$ (at $37^{\circ} \mathrm{C}$ ), $7.4 \times 10^{4} \pm 8.9 \times 10^{3}\left(\right.$ at $50^{\circ} \mathrm{C}$ ) and $3.1 \times 10^{4} \pm 4.3 \times 10^{3}$
(A)

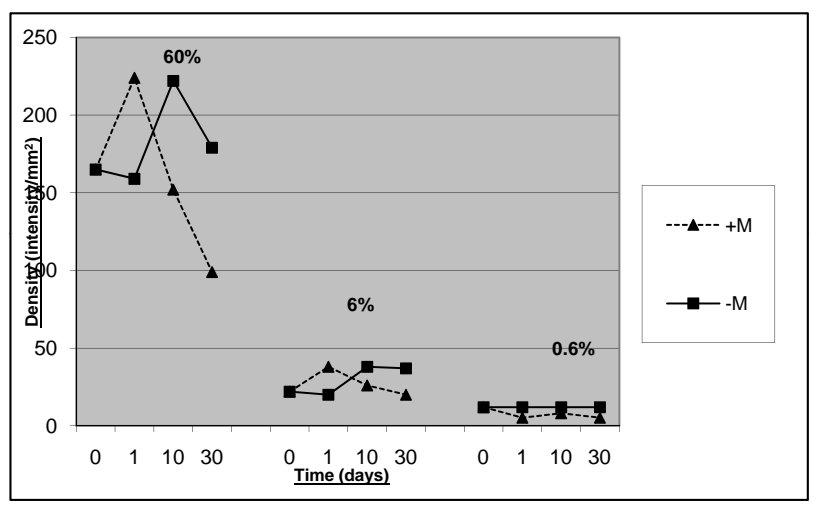

(B)

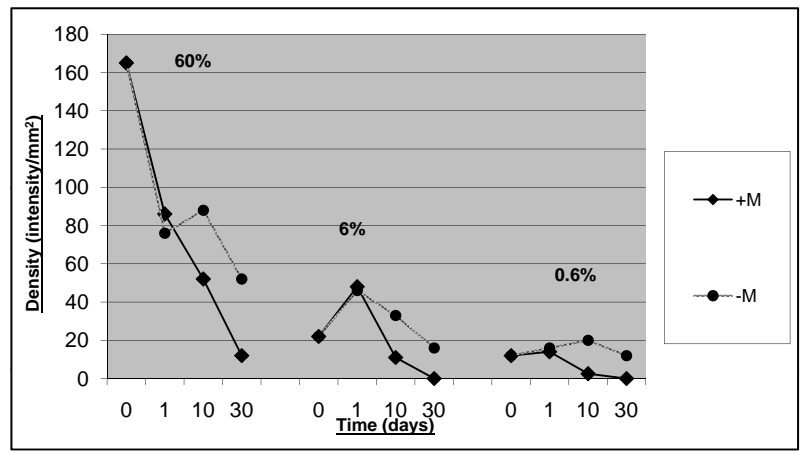

(C)

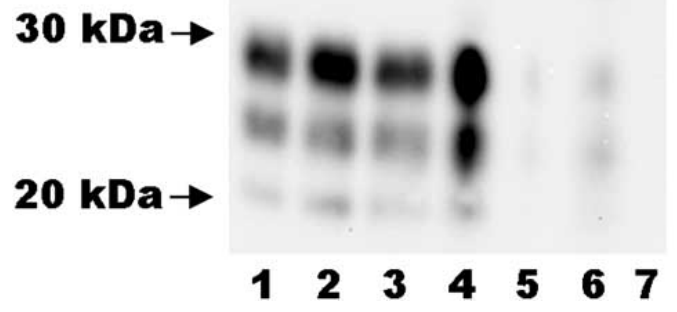

Fig. (1). Degradation of $\operatorname{PrP}^{\mathrm{Sc}}$ based on measurement of band density by $\mathrm{WB}$ in $60 \%, 6 \%$ and $0.6 \%$ scrapie CNS homogenates. $(\mathbf{A}, \mathbf{B})$ Band density of $\mathrm{PrP}^{\mathrm{Sc}}$ in $\mathrm{CNS}$ tissues with $(+\mathrm{M})$ or without (-M) addition of microbes after incubation at room temperature (RT) (A) or at $60^{\circ} \mathrm{C}$ (B) for 30 days. Density (intensity $/ \mathrm{mm}^{2}$ ) of all three $\mathrm{PrP}^{\mathrm{Sc}}$ bands $\times 10^{4}$. (C) Degradation of $\mathrm{PrP}^{\mathrm{Sc}}$ in $6 \%$ scrapie CNS incubated at $60^{\circ} \mathrm{C}$. Lane 1, day 0 control; lanes 2 and 3, day 1 , without (-M) or with $(+\mathrm{M})$ microbial inoculation respectively; lane 4 and 5, day 10, -M or $+\mathrm{M}$, respectively; lanes 6 and 7, day 30, Mor $\mathrm{M}+$, respectively. Note that on day $30, \mathrm{PrP}^{\mathrm{Sc}}$ was not detectable in the $\mathrm{M}+$ but was detectable in the $\mathrm{M}$ - specimen.

$\left(\right.$ at $60^{\circ} \mathrm{C}$ ) respectively. Therefore, the first experiment only compared the effects of microbes on degradation of $\operatorname{PrP}^{\mathrm{Sc}}$ at $60^{\circ} \mathrm{C}$ and at RT. The autoclaving for 5 minutes at $121^{\circ} \mathrm{C}$ reduced the numbers of bacteria by 6000 fold (from $1.8 \times 10^{5}$ $\mathrm{CFU} / \mathrm{ml}$ to $30 \mathrm{CFU} / \mathrm{ml}$ ) in the scrapie positive specimen and 1000 fold (to $2 \times 10^{4}$ to $2 \mathrm{CFU}$ ) $/ \mathrm{ml}$ in scrapie negative sheep brain suspension, respectively. As reported in Fig. (1A), after 30 days of incubation at RT there was no measurable reduction of $\mathrm{PrP}^{\mathrm{Sc}}$ band density in the autoclaved specimens that were not inoculated with microbes. In comparison, in the specimens inoculated with microbes and incubated in parallel, the density of the bands detected by WB were 
reduced by $40 \%$ and $10 \%$ for the homogenated specimens containing $60 \%$ and $6 \%$ scrapie CNS tissues, respectively. Fig. (1B) reports degradation of $\operatorname{PrP}^{\mathrm{Sc}}$ based on band density in specimens following 30 days of incubation at $60^{\circ} \mathrm{C}$. There were significantly higher reductions in the inoculated $(80.9$ with standard deviation $( \pm)$ of $14.9 \%, n=3)$ than in the uninoculated $(49.2 \pm 19.9 \%)$ specimens containing 60,6 and $0.6 \%$ of scrapie CNS tissues $(p<0.05$, paired $t$-test). The $\operatorname{PrP}^{\mathrm{Sc}}$ band was not visible after 30 days of incubation at $60^{\circ} \mathrm{C}$ in inoculated specimens that contained $6 \%$ or $0.6 \%$ scrapie CNS tissues but the bands were still visible in the uninoculated preparations (Fig. 1C).

In the second experiment, the levels of $\mathrm{PrP}^{\mathrm{Sc}}$ in tissues from all 4 scrapie positive sheep declined significantly throughout the 90 day incubation period at $60^{\circ} \mathrm{C}(p<0.05$, ANOVA) (Fig. 2A-C). On day 90 the $\operatorname{PrP}^{\mathrm{Sc}}$ had been degraded beyond the detection limit in specimens from 2 scrapie positive sheep but was detected in the other 2 sheep. $\mathrm{PrP}^{\mathrm{Sc}}$ was never detected in specimens from the four negative sheep (data not shown).

(A)

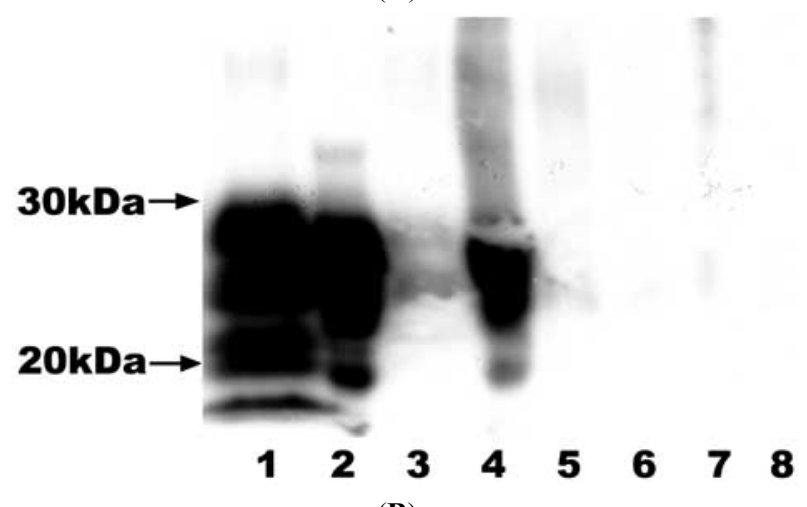

(B)

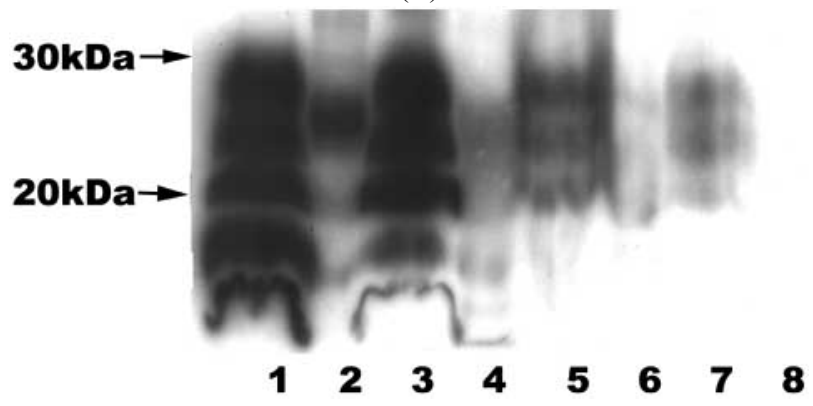

Fig. (2). Degradation of $\operatorname{PrP}^{\mathrm{Sc}}$ in $60 \%$ scrapie $\mathrm{CNS}$ tissue homogenates from individual sheep after incubation at $60^{\circ} \mathrm{C}$ in exp. 2. (A) Fate of $\mathrm{PrP}^{\mathrm{Sc}}$ in sheep \#4 (complete reduction). Odd lanes PTA, even lanes PK-. Lanes 1 and 2, day 0; lanes 3 and 4, day 30; lanes 5 and 6, day 60; lanes 7 and 8, day 90. (B) Partial reduction of $\mathrm{PrP}^{\mathrm{Sc}}$ in sheep \#2. Odd lanes PTA, even lanes PK-. Lanes 1 and 2, day 0 ; lanes 3 and 4, day 30; lanes 5 and 6, day 60; lanes 7 and 8 day 90. Measurement of band density of WB for degradation of $\mathrm{PrP}^{\mathrm{Sc}}$ in $\mathrm{CNS}$ tissues in experiment 2. The data represents the density (intensity $/ \mathrm{mm}^{2}$ ) of all three $\operatorname{PrP}^{\mathrm{Sc}}$ bands, x $10^{5}$. Samples \#1 to 4 were from scrapie positive sheep. $\mathrm{PrP}^{\mathrm{Sc}}$ was not detected in samples \#5 to 8 of scrapie negative sheep (data not shown).

\section{Microbial rDNA Profile Analysis}

The rDNA profiles reported in Fig. (3A) are from exp. 1 and include a profile for a protype mesophilic microbe. In the lanes where bands were above or below the mesophilic control, the microbes were considered to be in the range containing predominantly mesophilic or thermophilic, respectively. It was noted that the fecal microbial inoculum that was pre-incubated at RT with 8 passages, showed predominant bands in the upper portion of the gel whereas the inoculum pre-incubated at $60^{\circ} \mathrm{C}$ with 8 passages showed 2 predominant bands of microbial rDNA in the bottom portion of the gel, which further supported the distribution range of rDNA of mesophilic and thermophilic microbes. The bands for microbes that survived the brief period of autoclaving fell between those for mesophilic and thermophilic microbes. In the CNS homogenate inoculated with microbes and incubated at RT, there was no change in the position of the bands after 30 days. However, in the comparable specimen incubated at $60^{\circ} \mathrm{C}$, there was a prominent band in the thermophilic range.

In the second experiment the microbial $16 \mathrm{~S}$ rDNA profiles shifted from the mesophilic to the thermophilic range during 90 days incubation at $60 \mathrm{C}$. However, the band positions indicated that the predominant microbes in the two specimens were different (Fig. 3B).

\section{DISCUSSION}

The objective of this study was to investigate the capacity of microbes from the environment relevant to sheep to degrade $\mathrm{PrP}^{\mathrm{Sc}}$ in $\mathrm{CNS}$ tissues from scrapie positive sheep under in vitro conditions by measuring the degradation using a sensitive WB. Several previous studies have indicated that $\mathrm{PrP}^{S c}$ is at least partially degraded by thermostable enzymes or protease from Bacillus sp. [9-11], Streptomyces sp. [12, 13] and Nocardiopsis sp. [14], undefined microbes in cheese $[15]$ or in the rumen and colon of cattle $[16,17]$ as measured using either WB [9-13, 15-17] and bioassay [10]. The present study supported the results of the above studies, and gave further evidence that microbes that would likely be found in the carcasses of all dead sheep could play a role in the degradation of the $\operatorname{PrP}^{\mathrm{Sc}}$ in CNS tissue suspensions prepared from scrapie infected sheep under in vitro conditions. However, due to the difficulties to control all the conditions, other unknown factors may also play roles in the degradation of $\mathrm{PrP}^{\mathrm{Sc}}$ under the conditions in this study.

While it is likely that the microbes may invade the CNS tissues following the death of the animals [24], contamination could also occur during collection of the tissues at necropsy. Autoclaving at $121^{\circ} \mathrm{C}$ for 5 minutes reduced the number of microbes in the CNS tissue suspensions for exp. 1, but based on $16 \mathrm{~S}$ rDNA profiles, those microbes that survived included mesophiles and thermophiles. The degradation of $\operatorname{PrP}^{\mathrm{Sc}}$ was presumed to be mainly due to the activity of thermophilic organisms since thermophiles were detected 1) in the inoculum prepared at $60^{\circ} \mathrm{C}$ after 8 passages that was used for incubation at $60^{\circ} \mathrm{C}$ and the specimens incubated at $60^{\circ} \mathrm{C}$ for over 3 month and not at RT, and degradation only occurred at $60^{\circ} \mathrm{C}$. Addition of fecal microbes to specimens increased the rate of degradation that took place during incubation at $60^{\circ} \mathrm{C}$. It is likely that the slow rate of degradation of abnormal prions in exp. 2 was due to low numbers of microbes with the capacity to cause degradation. In that experiment, the only microbes 
(A)

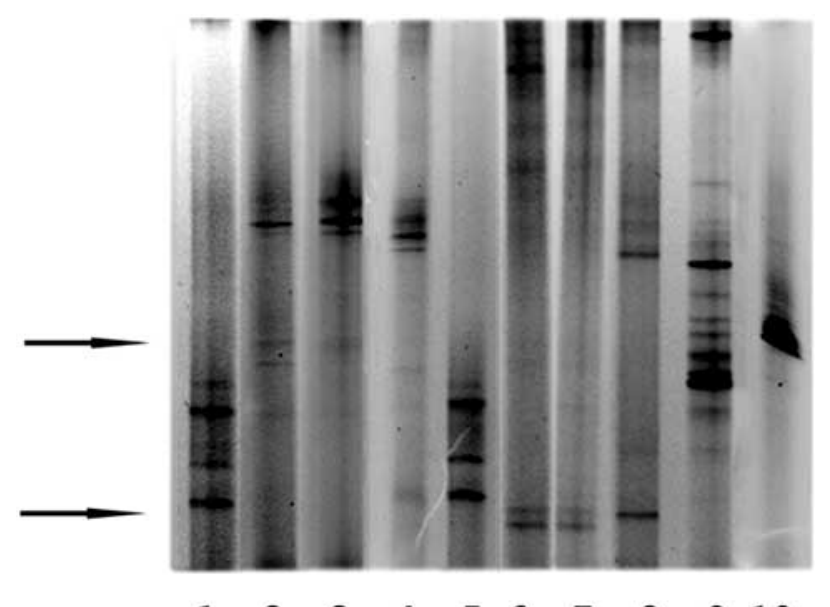

$\begin{array}{llllllllll}1 & 2 & 3 & 4 & 5 & 6 & 7 & 8 & 9 & 10\end{array}$

(B)

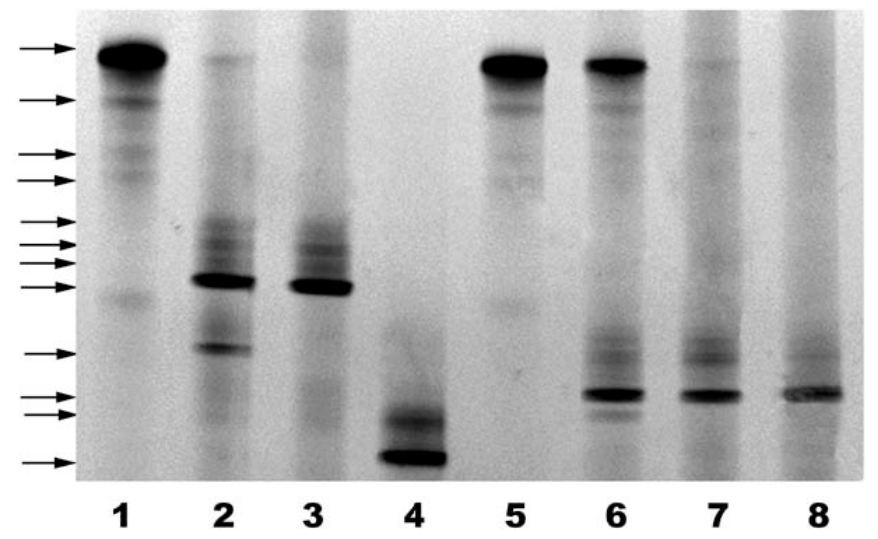

Fig. (3). (A) Microbial DNA profile in samples incubated in exp. 1. Specimens consisting of a $60 \%$ scrapie CNS tissue homogenate are referred to as a scrapie specimen. Lane 1 , scrapie specimen on day 0 ; lane 2, day 0 , ovine fecal microbes pre-incubated at RT; lanes 3 and 4, scrapie specimen inoculated with microbes (pre-incubated at RT), then incubated at RT and tested on day 1 and 30 respectively; lane 5, scrapie specimen without inoculation of microbes, incubated at RT and tested on day 30; lane 6 , day 0 , ovine fecal microbes pre-incubated at $60^{\circ} \mathrm{C}$; lanes 7 and 8 , scrapie specimen inoculated with microbes (pre-incubated at $60^{\circ} \mathrm{C}$ ), then incubated at $60^{\circ} \mathrm{C}$ and tested on day 1 and 30, respectively; lane 9, scrapie specimen without inoculation of microbes, incubated at $60^{\circ} \mathrm{C}$ and tested on day 30 ; lane 10 , mesophilc microbe control, a Pseudomonas chlororaphis strain. The bands at higher position in the gel (at or above the position of the mesophilc microbe control) are at lower gradient levels, have lower GC content and are predominantly mesophilc microbes. The bands at lower positions in the gel (below the band of mesophilc control) are at higher gradient levels, have higher GC content and are predominantly thermophilic microbes (15). Top arrow indicates the band of Pseudomonas chlororaphis control. The bottom arrow indicates the approximate position of thermophilic microbes that grow at $60^{\circ} \mathrm{C}$. (B) Exp. 2. Microbial DNA in specimens incubated at $60^{\circ} \mathrm{C}$. Lanes $1-4$, CNS of sheep \#1. Lanes $5-8$, CNS of sheep \#2 on days $0,30,60$ and 90 , respectively. The bands at lower positions have higher GC content and are predominantly thermophilic microbes. were those that were in the specimens at the time they were collected and the only nutrients were in the CNS tissue that was suspended in saline. Nevertheless, during the 90 day incubation period at $60^{\circ} \mathrm{C}$, the $\operatorname{PrP}^{\mathrm{Sc}}$ was gradually degraded in all specimens and at termination; the degradation was beyond the detection limit in specimens from 2 of the 4 sheep. The rDNA profiles showed a similar pattern of switching from a predominant population of mesophiles to a predominant population of thermophiles during incubation. The observation that the profiles for the thermophilic microbes in the two specimens differed, suggested that many different microbes may contribute to the degradation process.

The present study did not investigate the survival of infectivity following in vitro incubation and there is need for this information before degradation of animal tissues by microbes could be recommended for disposal of animal carcasses infected with the scrapie agent. One report showed that the $\mathrm{PrP}^{\mathrm{Sc}}$ in scrapie infected hamster brain could be degraded by bovine rumen microbes within 40 hours under in vitro conditions but the specimen retained infectivity [17]. Another study, however, showed that a thermostable protease reduced the infectivity of bovine spongiform encephalopathy infectious mouse brain homogenate during a 30 minute incubation period at $60^{\circ} \mathrm{C}$ [10]. The latter report is encouraging as in the composting process, extensive enzymatic activity from a wide variety of microbes, would be expected to contribute to the degradation of animal tissues. In one composting study [8], $\mathrm{PrP}^{\mathrm{Sc}}$ in tissue from affected sheep was degraded beyond the detection limit even though temperatures at about $60^{\circ} \mathrm{C}$ that are most suitable for thermophilic microbes only persisted for 2 to 3 weeks.

Western blot procedure was used in this study to detect $\mathrm{PrP}^{\mathrm{Sc}}$. It is commonly believed that $\mathrm{WB}$ assay is not as sensitive as a bioassay and can not detect infectivity. Some studies indicated that detection of $\mathrm{PrP}^{\mathrm{Sc}}$ is not always correlated with infectivity after treatment with enzymes, detergents or heat $[10,25-28]$. This fact could be due to the different time course or mechanisms of the $\mathrm{PrP}^{\mathrm{Sc}}$ degradation and inactivation during different treatments [29]. However, WB assay has been shown to be a valuable tool for initial studies and predicators for infectivity [30-32], and has been used commonly for the studies of $\operatorname{PrP}^{\mathrm{Sc}}$ degradation and inactivation [8-13, 15-17, 30-32]. The WB procedure used in this study is highly sensitive which employed a $\operatorname{PrP}^{\mathrm{Sc}}$ enrichment procedure by PTA precipitation which enhances the sensitivity for 100 fold than conventional WB without enrichment [33]. It is noteworthy that the Mab F99/97.6.1 used for the WB procedure binds to residues 220 to 225 of the C-terminus of prion protein [34], and this region is a part of $\mathrm{PrP}^{\mathrm{Sc}}$ and relatively resistant to $\mathrm{PK}$ cleavage [1]. The negative results for $\mathrm{PrP}^{\mathrm{Sc}}$ in some treated samples based on the WB appear to indicate that $\operatorname{PrP}^{\mathrm{Sc}}$ had been degraded to the undetectable level by this method. However, further investigation to ensure the complete degradation of $\mathrm{PrP}^{\mathrm{Sc}}$ into smaller polypeptide or peptides would be necessary.

This study showed that a variety of thermophilic microbes could contribute to the degradation of $\mathrm{PrP}^{\mathrm{Sc}}$ and that these organisms could survive on the nutrients that were in the CNS tissues. However, the results suggest that large numbers of a variety of actively proliferating microbes, such 
as those would be found in a composting pile at about $60^{\circ} \mathrm{C}$, would increase the chances for efficient destruction of abnormal prions. Further investigation to identify the microbes, particularly the thermophilic, that could contribute to the degradation of $\operatorname{PrP}^{\mathrm{Sc}}$ would be important to understand the mechanisms for the interactions between $\operatorname{PrP}^{\mathrm{Sc}}$ and microbes, and for further use in inactivation or destruction of $\mathrm{PrP}^{\mathrm{Sc}}$.

\section{ACKNOWLEDGEMENTS}

The authors thank Dr. A. Balachandran for providing samples and professional help; Y. Feng, J. Rendulich, J. Srighanthan, S. Foster, P. Maattanen and N. Yogasingam for technical help in sample preparation and for Western blot testing; Chris Grenier for technical help in bacterial DNA analysis; J-M Lapointe for imaging. This study was supported by research funds of Canadian Food Inspection Agency.

\begin{tabular}{|c|c|}
\hline \multicolumn{2}{|c|}{ ABBREVIATIONS } \\
\hline $\mathrm{PrP}^{\mathrm{Sc}}$ & $=$ Abnormal prion protein \\
\hline CNS & $=$ Central nervous system \\
\hline $\mathrm{RT}$ & $=$ Room temperature $\left(22 \pm 2{ }^{\circ} \mathrm{C}\right)$ \\
\hline $\mathrm{G}+\mathrm{C}$ content & $\begin{aligned} &= \text { Guanine-cytosine content of a DNA } \\
& \text { molecule }\end{aligned}$ \\
\hline rRNA & $=$ Ribosomal RNA \\
\hline rDNA & $=$ Ribosomal DNA \\
\hline TSEs & $\begin{aligned}= & \text { Transmissible spongiform } \\
& \text { encephalopathies }\end{aligned}$ \\
\hline WB & $=$ Western blot \\
\hline $\mathrm{PC}$ & $=$ Plate count \\
\hline CFU & $=$ Colony forming unit \\
\hline PTA & $=$ Sodium phosphotungstic acid \\
\hline PK & $=$ Protease $\mathrm{K}$ \\
\hline PCR & $=$ Polymerase chain reaction \\
\hline
\end{tabular}

\section{REFERENCES}

[1] Prusiner SB. Prions. Proc Natl Acad Sci USA 1998; 95: 13363-83.

[2] Taylor DM. Inactivation of transmissible degenerative encephalopathy agents: a review. Vet J 2000; 159(1): 10-7.

[3] Brown P, Rau EH, Johnson BK, Bacote AE, Gibbs CJ, Gajdusek DC. New studies on the heat resistance of hamster-adapted scrapie agent: threshold survival after ashing at 600 degrees $\mathrm{C}$ suggests an inorganic template of replication. Proc Natl Acad Sci USA 2000; 97: 3418-21.

[4] Brown P, Rau EH, Lemieux P, Johnson BK, Bacote AE, Gajdusek DC. Infectivity studies of both ash and air emissions from simulated incineration of scrapie-contaminated tissues. Environ Sci Technol 2004; 38: 6155-60.

[5] Brown P, Gajdusek DC. Survival of scrapie virus after 3 years' interment. Lancet 1991; 337: 269-70.

[6] Taylor DM, Woodgate SL. Rendering practices and inactivation of transmissible spongiform encephalopathy agents. Rev Sci Tech 2003; 22: 297-310.

[7] Glanville TD, Trampel DW. Composting alternative for animal carcass disposal. J Am Vet Med Assoc 1997; 210: 1116-20.

[8] Huang H, Spencer JL, Soutyrine A, Guan J, Rendulich J, Balachandran A. Evidence for degradation of abnormal prion protein in tissues from scrapie affected sheep during composting. Can J Vet Res 2007; 71: 34-40.
[9] Langeveld JP, Wang JJ, Van de Wiel DF, et al. Enzymatic degradation of prion protein in brain stem from infected cattle and sheep. J Infect Dis 2003; 188: 1782-9.

[10] McLeod AH, Murdoch H, Dickinson J, et al. Proteolytic inactivation of the bovine spongiform encephalopathy agent. Biochem Biophys Res Commun 2004; 317: 1165-70.

[11] Yoshioka M, Miwa $\mathrm{T}$, Horii $\mathrm{H}$, et al. Characterization of a proteolytic enzyme derived from a Bacillus strain that effectively degrades prion protein. J Appl Microbiol 2007; 102: 509-15.

[12] Hui Z, Minamiguchi K, Doi H, Kinoshita N, Kanouchi H, Oka T. Recombinant alkaline serine protease II degrades scrapie isoform of prion protein. In vitro Cell Dev Biol Anim 2004; 40: 293-6.

[13] Hui Z, Doi H, Kanouchi H, et al. Alkaline serine protease produced by Streptomyces sp. degrades $\operatorname{PrP}(\mathrm{Sc})$. Biochem Biophys Res Commun 2004; 321: 45-50.

[14] Mitsuiki S, Hui Z, Matsumoto D, et al. Degradation of $\operatorname{PrP}(\mathrm{Sc})$ by keratinolytic protease from Nocardiopsis sp. TOA-1. Biosci Biotechnol Biochem 2006; 70: 1246-8.

[15] Müller-Hellwig S, Martin H, Groschup NH, et al. Biochemical evidence for the proteolytic degradation of infectious prion protein $\mathrm{PrP}^{\mathrm{Sc}}$ in hamster brain homogenates by foodborne bacteria. Syst Appl Microbiol 2006; 29: 165-71.

[16] Scherbel C, Pichner R, Groschun MH, et al. Degradation of scrapie associated prion protein $\left(\operatorname{PrP}^{(\mathrm{Sc})}\right)$ by the gastrointestinal microbiota of cattle. Vet Rec 2006; 37: 695-703.

[17] Scherbel C, Pichner R, Groschup MH, et al. Infectivity of Scrapie Prion Protein $\left(\mathrm{PrP}^{\mathrm{Sc}}\right)$ Following In vitro Digestion with Bovine Gastrointestinal Microbiota. Zoonoses Public Health 2007; 54: 185-90.

[18] Huang H, Rendulich J, Stevenson DA, O'Rourke K, Balachandran A. Comparison of western blotting methods using samples with or without sodium phosphotungstic acid precipitation for diagnosis of scrapie and chronic wasting disease in Canada. Can J Vet Res 2005; 69: 193-9.

[19] Schwieger F, Tebbe CC. A new approach to utilize PCR-single-strand-conformation polymorphism for 16S rRNA gene-based microbial community analysis. Appl Environ Microbiol 1998; 64: 4870-6.

[20] Zoetendal EG, Akkermans AD, de Vos WE. Temperature gradient gel electrophoresis analysis of 16S rRNA from human fecal samples reveals stable and host-specific communities of active bacteria. Appl Environ Microbiol 1998; 64: 3854-9.

[21] Olsen GJ, Woese CR. Ribosomal RNA: a key to phylogeny. FASEB J 1993; 7: 113-23.

[22] Galtier N, Tourassen N, Gouy M. A nonhyperthermophilic common ancestor to extant life forms. Science 1999; 283: 220-1.

[23] Kimura H, Sugihara M, Kato K, Hanada S. Selective phylogenetic analysis targeting $16 \mathrm{~S}$ rRNA genes of hyperthermophilic archaea in the deep-subsurface hot biosphere. Appl Environ Microbiol 2006; 72: $21-7$

[24] Gill CO, Penney N, Nottingham PM. Effects of delayed evisceration on the microbial quality of meat. Appl Environ Microbiol 1976; 31: 465-68.

[25] Kimberlin RH., Walker CA, Millson GC, et al. Disinfection studies with two strains of mouse-passaged scrapie agent. Guidelines for Creutzfeldt-Jakob and related agents. J Neurol Sci 1983; 59: 355-69.

[26] Manuelidis L, Sklaviadis T, Manuelidis EE. Evidence suggesting that $\operatorname{PrP}$ is not the infectious agent in Creutzfeldt-Jakob disease. EMBO J 1987; 6: 341-7.

[27] Wille H, Prusiner SB, Cohen FE. Scrapie infectivity is independent of amyloid staining properties of the N-terminally truncated prion protein. J Struct Biol 2000; 130: 323-38.

[28] Somerville RA, Oberthür RC, Havekost U, MacDonald F, Taylor DM, Dickinson AG. Characterization of thermodynamic diversity between transmissible spongiform encephalopathy agent strains and its theoretical implications. J Biol Chem 2002; 277: 11084-9.

[29] Taylor DM, Fernie K, Steele PJ, McConnell I, Somerville RA. Thermostability of mouse-passaged BSE and scrapie is independent of host PrP genotype: implications for the nature of the causal agents. J Gen Virol 2002; 83: 3199-204.

[30] Appel TR, Lucassen R, Groschup MH, Joncic M, Beekes M, Riesner D. Acid inactivation of prions: efficient at elevated temperature or high acid concentration. J Gen Virol 2006; 87: 1385-94. 
[31] Brown P, Meyer R, Cardone F, Pocchiari M. Ultra-high-pressure inactivation of prion infectivity in processed meat: a practical method to prevent human infection. Proc Natl Acad Sci USA 2003; 100: 6093-7.

[32] Morales R, Buytaert-Hoefen KA, Gonzalez-Romero D, et al. Reduction of Prion Infectivity in Packed Red Blood Cells. Biochem Biophys Res Commun 2008; 377: 373-8.
[33] Huang H, Rendulich J, Stevenson D, O'Rourke K, Balachandran A. Evaluation of Western blotting methods using samples with or without sodium phosphotungstic acid precipitation for diagnosis of scrapie and chronic wasting disease in Canada. Can J Vet Res 2005; 69: 193-9.

[34] O'Rourke KI, Baszler TV, Besser TE, et al. Preclinical diagnosis of scrapie by immunohistochemistry of third eyelid lymphoid tissue. J Clin Microbiol 2000; 38: 3254-9.

(C) Huang et al.; Licensee Bentham Open.

This is an open access article licensed under the terms of the Creative Commons Attribution Non-Commercial License (http://creativecommons.org/licenses/by-nc/ $3.0 /$ ) which permits unrestricted, non-commercial use, distribution and reproduction in any medium, provided the work is properly cited. 